<原 著 $>$

\title{
四塩化炭素による师障害ラットにおける脺の 内分泌機能ならびに形態的変化
}

橋本仁樽谷 英二崩隆史梅山馨*

\begin{abstract}
要 旨 : 肝と脺との関係について, 種々の報告があるが，とりわけ肝障害時の膵の機能ならびに 形態的変化についてはいろいろ議論されており，とくに肝の脺への影響についていまだ不明な点 が多い，われわれは，今回，実験的に四塩化炭素をラットの腹腔内に投与することによって作成 した種々の程度の肝障害ラットについて，萃内分泌細胞の形熊的変化を中心に電顕にて検討し た。攵の結果, 肝障害の軽度なものではラ氏島 B 細胞の機能六進像がみられた。るた高度のもの ではラ氏島 $A / B$ 比の増大傾向が観察され, 同時に IRG の著しい上昇もみられた.
\end{abstract}

索引用語：四塩化炭素実験的肝障害 膵内分泌細胞

\section{I. 緒 言}

近年, 肝膵相関の一環として，肝障害時の膰の機能 ならびに形態的変化についてはいろいろ議論されてい

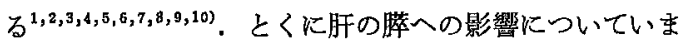
た不明な点が多いるわれわれはさき胿硬変症患者 (とくに乙型肝硬変)の脺内分泌細胞の電顕的所見につい て検討し，一般にB 細胞に比べてA 細胞では比較的よく その微細構造が保存されているのに対し，B細胞ではか なり著明な退行性変化がみとめられることをのぺだリ。

今回は, 実験的飞四塩化炭素をラットの腹控内飞投与す ることによって作成した種くの程度の肝障害ラットにつ いて，膵内分泌細胞の形態的変化を中心に，光顕扝よび 電顕的検討を加光た. 同時に，これらラットの血中のイ ソスリン (IRI) およびグルカゴン（IRG）值を測定し， 若下の知見を得たので報告する。

\section{II. 実験材料および方法}

約50匹のウイスター系ラット(合，体重200〜250g の もの：日本クレア) K流動パラフィンで10倍に肴釈した 四塩化炭素を $3 \mathrm{~m} l / \mathrm{kg}$ の量で，週 2 回，1.5力月から 4 カ月間腹整内注入した. 肝実質細胞の障害度によっ て光影所見より軽度なるのより順に liver fibrosis, liver cirrhosis B, liver cirrhosis A の 3 グループに分類し, それぞれの膆内分泌細胞についてとくに電顕的变化につ

* 大阪市立大学医学部第一外科 $<$ 受付日 57 年 3 月 3 日 $>$
いて検討した。またこれらのラットは屠殺時に空腹時血 糖，IRI，IRG などを測定した，採取した肝拉よび脺組 織標本は光顕標本として10\%ホルマリンにて固定し，電 顕標本は採取後ただらに $4 \%$ グルタールアルデヒドと 1 \%オスミウムにて二重固定を行ない,エタノール系列で 脱水後エポン包埋を行なった，血清中の IRI は固相法 で測定し，血浆中の IRG は Unger の antibody を用い て測定した.

\section{III. 成 績}

人肝硬变患者にみられるのと同様に，実験的肝硬変ラ

Table 1. The basal serum IRI and IRG are demonstrated in various liver damages.

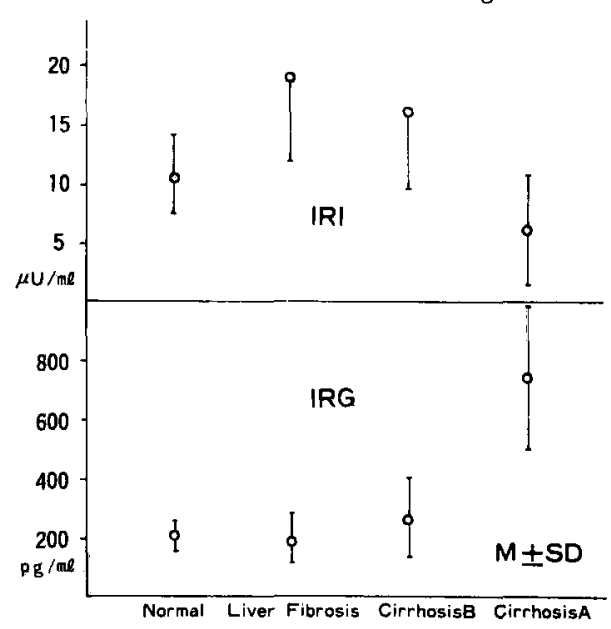


ットに招いても Table 1 にみられるように IRI 括よび IRG 値に変動がみられ，架腹時の IRI 拉よび IRG は 一般に上昇する傾向がみられたが，それら屾肝組織の障 害程度によって異なっていた。即ち，肝組織の障害の 比較的軽徽なるの (liver fibrosis 括よび liver cirrhosis B）ではIRI 値の著しい上昇がみられたが，IRG 值では 上昇㑯向がらかがわれたが著明ではなかった，一方，肝 組織障害のすすんだもの (liver cirrhosis A) では IRI 檤はむし，低值を示し，逆に IRG 值が高値を示した。

1) liver fibrosis : Fig. 1 は liver fibrosis の肝の hematoxylin-eosin 染色の標本で, 四塩化宸素腹腔内投 与約1.5力月目で, 中心静脈周囲 やダリソン鞘に軽度の 線維化が認められ，肝細胞索のみだれがみられた。 また 肝細胞は中心静脈付近で崩罣像もみられ，大小多数の空 胞がみられた，一方，膵の組織学的所見では，全般的に ラ氏島紐胞の肥大傾向がみられ，著明な退行性変化はみ

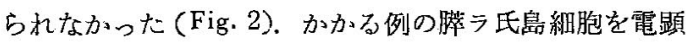
にて観察すると，A 緗胞については正常膆のるのに比較 してとくに著変はみられなかったが，B細胞では Golgi 装置の発達は著明で, それらの顆粒の数の增加傾向や顆 粒の core の density の著しい增強がみられ，さらに幼 若顆粒とラインデームの增加がらかがわれる (Fig. 3). また，Fig. 4 のごとく細胞間隙のところどころに分泌顆 精の density と同様な density を有する amorphous な物 質の存在がみられた。

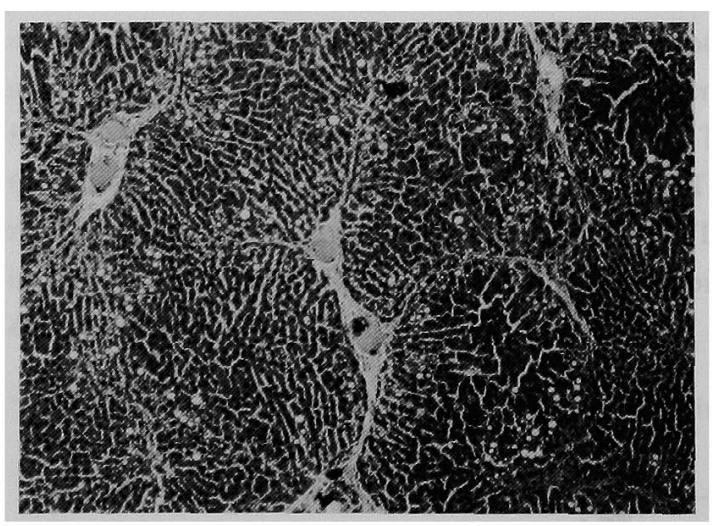

Fig. 1 Light micrograph pof the liver fibrosis, which is induced by $\mathrm{CCl}_{4}$ for 1.5 months. Fibrosis is observed around the central vein and in the capsule of Glisson. The hepatocyte near to the central vein is destructed, and in the cell, aboundant vacuoles varing in diameter are seen. $(x 40)$

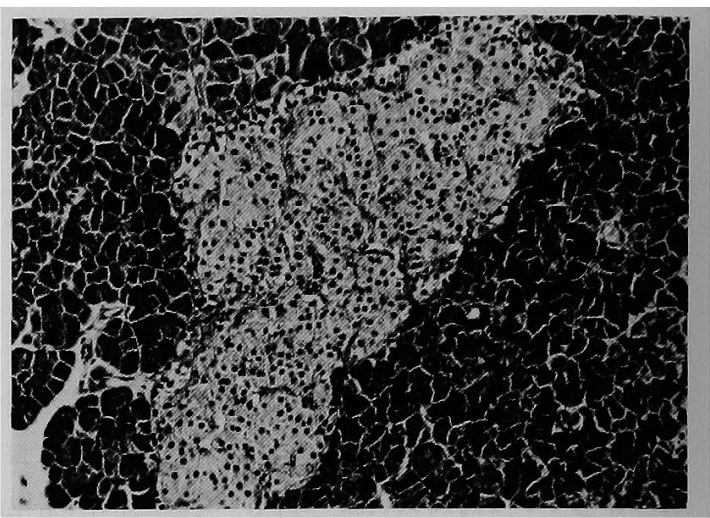

Fig. 2 The pancreatic islet in the liver fibrosis is tendency of hypertrophy in its diameter. No degenerating change is observed. $(\times 100)$

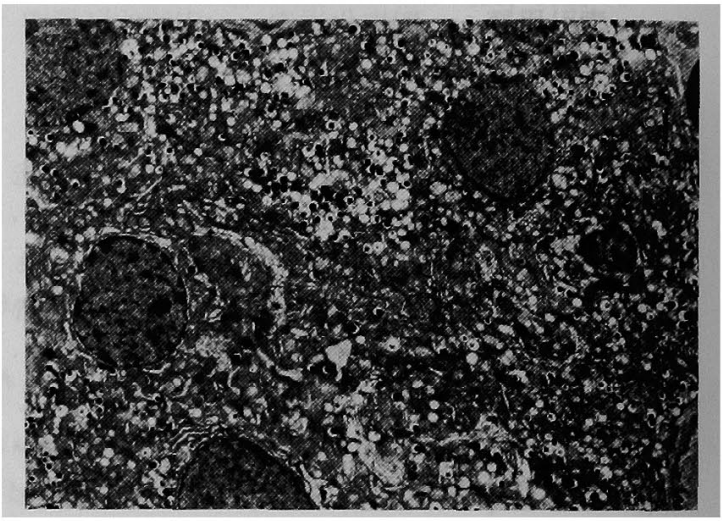

Fig. 3 Electron micrograph of the pancreatic islet cells in the liver fibrosis. In the B cells of the islet, the Golgi complex and the cytoplasmic organelles are well developed. Abundant secreting granules are seen, and the density of the granules is high. $(x 2200)$

2) liver cirrhosis B : Fig. 5 は liver cirrhosis B の肝組織像で，四塩化炭素腹蕗内投与開始後約 3 力月目 では，小集は大小の偽小葉比改築され，肝細胸索の及拉 れは liver fibrosis よりもより著明となり，䀒細胞の萎 綰，崩壤がより強くなり空胞も散在してみられた。かか る例の膵ラ氏島のB細胞では Fig. 6 のごとく，Golgi 装 置の発達は良好で, 分泌顆粒る豊富で, ライソゾームも 多くみられたが, liver fibrosis の膵のB細胞のよらに分 泌顆粒の density が著しく高い core を有する顆粒や細 胞間隙に存在した density の高い amorphous な物碩はま とんどみられなかった，三氏島 $\mathrm{A}$ 細胞については。形態 


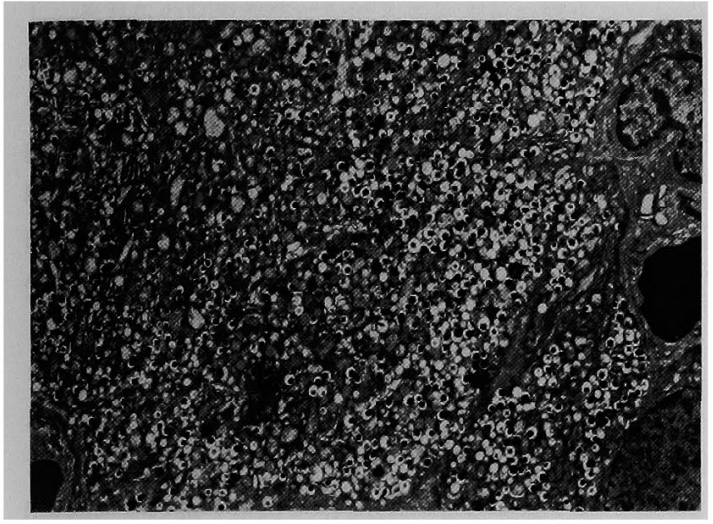

Fig. 4 Electron micrograph of the pancreatic islet cells in the liver fibrosis. Abundant secreting granules are seen. The lysosome is increasing. In the spaces between the $B$ cells, the electron dense material is observed. $(\times 2200)$

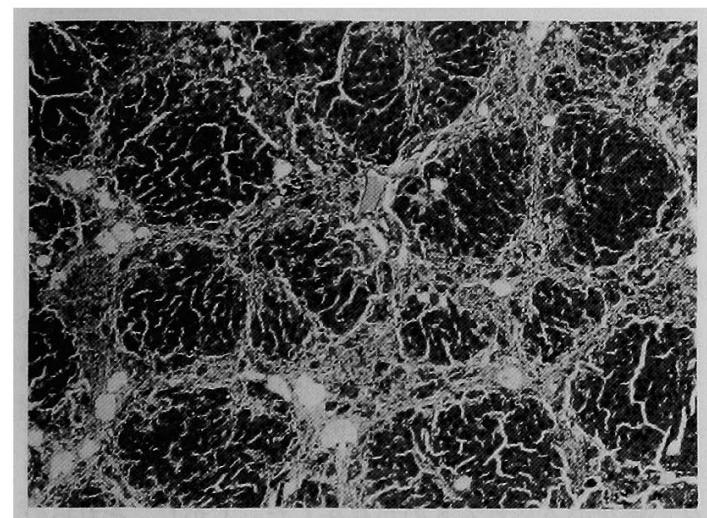

- Fig. 5 Light micrograph of the liver cirrhosis B, which is induced by inoculating of $\mathrm{CCl}_{4}$ for 3 months. The normal lobular structure is divided into regenerating nodules which are of variable size. Pseudolobules are separated by irregular bands of fibrous connective tissue. Disarrangement of hepatic plates is more markedly than that of the liver fibrosis. $(x 100)$

的に恃正常のものに比しほとんど差異がみとめられなか った.

3) liver cirrhosis $\mathbf{A}$ : Fig. 7 liver cirrhosis $A$ の肝組織像で，四塩化炭素投与開始後約 4 カ月目で, 偽 小葉は liver cirrhosis B よりるより小さくなり, 偽小葉 間の線維の幅は liver cirrhosis B よりも払大した像がみ られた。肝細胞は小型で細胞崩壊が著明となり，肝細胞 索のみだれもより高度であった.このような肝組織像を

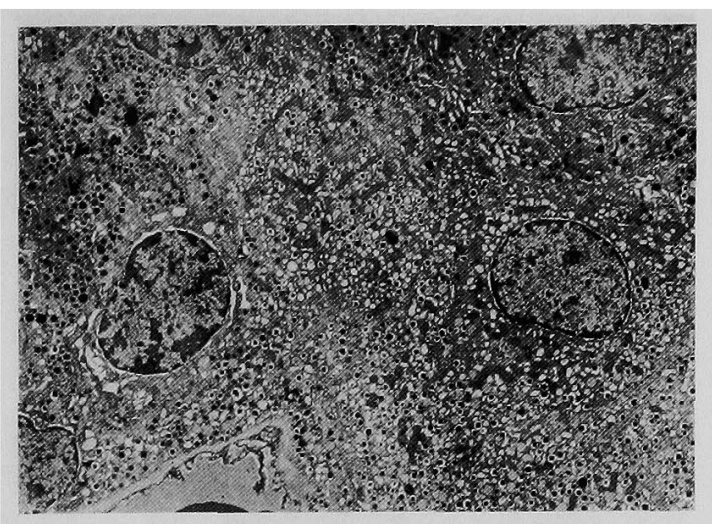

Fig. 6 Electron micrograph of the pancreatic islet in the liver cirrhosis $B$. In the $B$ cells, the intracytoplasmic organelles are well development. But the density of the secreting granules is lower than that in the liver fibrosis. In the spaces between the $B$ cells, the electron dense material is not observed. $(\times 2200)$

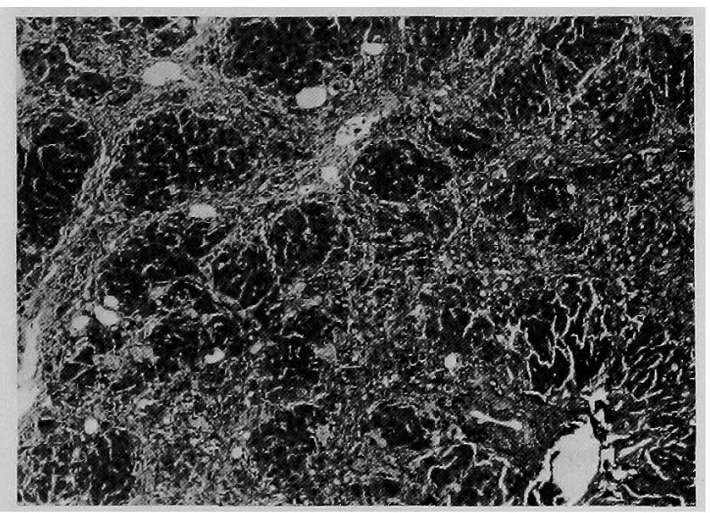

Fig. 7 Light micrograph of the liver cirrhosis A, which is induced by inoculating of $\mathrm{CCl}_{4}$ for 4 months. The fibrous tissue, around regenerating nodules, is remarkablly developed in width. The hepatic cell is small or destructed, and dearrangement of the hepatic plates is more marked than that in the liver cirrhosis B. $(\times 100)$

呈寸る脺ラ氏泉細胞の所見は，ラ氏島 B 細胞では分泌顆 粒も多く, Golgi 装置のよいものるみられるが, 粗面小 胞体の槽の拡大がみられ，槽内には amorphous な物質 のみられないるのが多くみられた (Fig. 8). さらに変 化の著しいものでは, 細胞質全体の density が箸しく增 加し，細胞萎縮を思わせる像がよくみられた (Fig. 9). そのほか, lipid droplets の出現や分泌顆粒の娍少傾向 


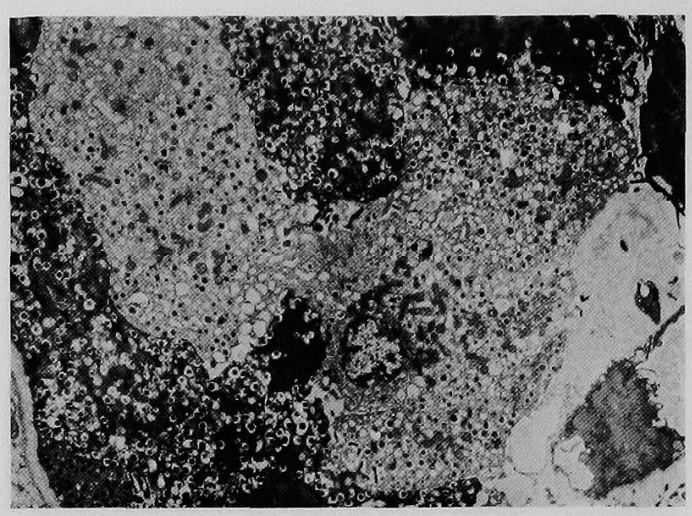

Fig. 8 Electron micrograph of the pancreatic B cells in the liver cirrhosis $A$. The cisternae of the rough endoplasmic reticulum is swollen and enlarged. $(\times 2200)$

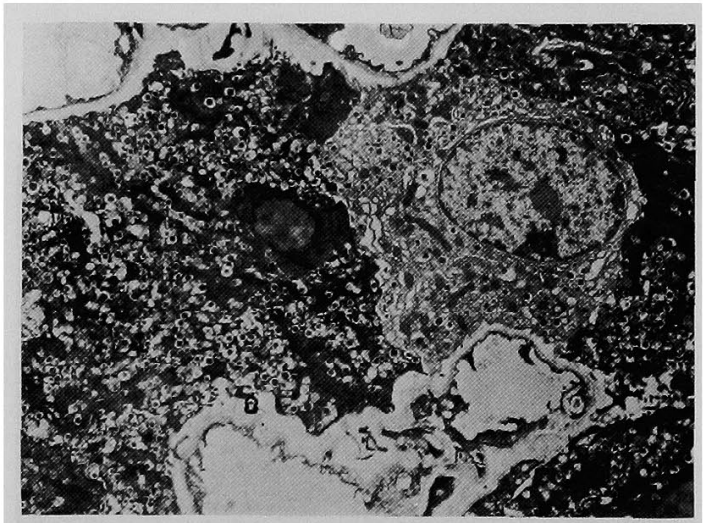

Fig. 9 Electron micrograph of the B cells in liver cirrhosis A. The density of the cytoplasmincreases markedly. The shrinkage of the $B$ cells is seen near and here. $(\times 2200)$

のみられるすのも存在した. 一方，A細胞については， それらの細胞数の増加, 即ら， A/B 比の增大傾向がうか がわれ，Fig. 10のごとく分泌顆粒も豊富で，Golgi 装置 の発達も良好で， B 細胞にみられたような退行性変化の 像は在とえどみられなかった。

\section{IV. 考 察}

近年, 臓器相関が論じられているなかで，とくに肝と 膵との関係について諸家に上り多くの研究報告がなされ ている1,2,3 4,5,6). われわれる人の肝硬変症患者の膵の機

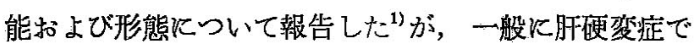
は，耐糖能の低下，高インスリン血症そして高グルカゴ ソ血症など脺内分泌ホルモンの異常がみとめられること

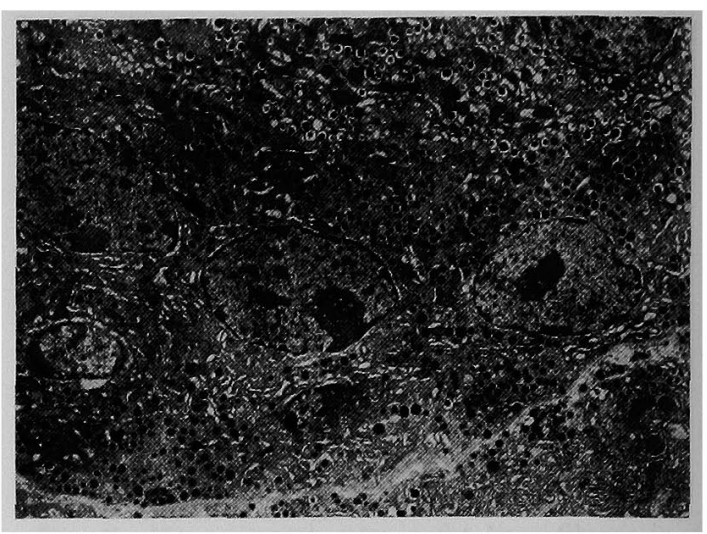

Fig. 10 Electron micrograph of the A cells in the liver cirrhosis A. The intracytoplasmic organelles is well developed. The number of the A cell increases and the ratio $A$ and $B$ is a tendency to increase. No degenerating change in the $A$ cell is observed. $(\times 2200)$

はすでに周知のことである，かつて，われわれは肝硬変 症患者之くに乙型肝硬変症の脺の形態的檢討を光顕的な らびに電顕的に行ない，膵内分泌細胞のうら B 細胞の 一部には細胞機能の活発な像を示唆する所見がみられた が，多くのB細胞では分泌顆粒の減少，それらの分泌顆 粒の core の density の低下, core を有しない顆粒の增 加, 粗面小胞体の膨化，さらにはこれらの空胞化形成然 みられ，細胞萎縮像を呈するものも存在した，一方，そ れに反して，A 細胞では比較的よくその構造が保持され て扣り,ごく一部のA 細胞にミトュンドリアや粗面小胞 体の膨化のみられるすのが存在した. しかし，それらの 変化む軽微であった．肝硬変症患者の荟内分泌細胞の組 織学的検索結果については, 武内 ${ }^{11)}$, 大坪 ${ }^{41}$, 山吹 ${ }^{12)} ら$ の報告によれば，脺内分泌細胞に障害があるとは結論し がたく，むしろ反対に脺内分泌細胞の機能方進さえ疑わ れる所見るみられているとのべている。，一方，川村沙 肝障害時の勝ラ氏島細胞の光影的所見として, ラ氏島組 胞の粗槳化, ピクノーゼ, A： B 細胞比の増大異常およ び硝子化などをあげているまた，このようなラ氏鳥細 胞の光顕所見は糖尿病患者のラ氏島細胞の病変に類似し ているが，その程度は比較的軽く，かかる脺ラ氏島の形 態的変化は肝病変の進展程度によって進行するものであ ららと推論している.

今回，われわれは，胢障害の膵におよぼす影響をより 具体的に把握するために実験的に四塩化炭素をラットの 㙏腔内に投与して，種々の程度の肝障害ラットを作成 
しそそれらの肝障害時に拈けるそれぞれの膵内分泌細胞 の機能と形熊的变化について検討した，その結果，肝実 質細胞の障害並びに肝の線維化程度飞よって，とくに線 維化の軽度なすのより, liver fibrosis, liver cirrhosis $\mathrm{B}$, liver cirrhosis A の3つのグループに分けると, liver fibrosis p liver cirrhosis B では IRI 值は上昇し, IRG 值炕すやや上昇傾向がらかがわれたが著变はみられなか った. 一方, liver cirrhosis A では IRI 值はむしろ低值 を示し，IRG 値牥逆著明な高値を示した，しかし， それらの理由，意義および機序については不明である。 これらの膵を電顕にて微細構造を検討した結果, liver

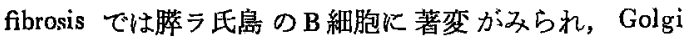
装置の発達は著明で 顆粒の 增加傾向やそれらの顆粒の density の著しい增加がみられ，さらに幼若顆粒とライ ソゾームの増加がらかがわれた。 さらに細胞間隚のとこ ろどころに顆粒の density に類似した amorphous な物質 の存在がみられた。それら amorphous な物質は分泌さ れたインスリンであるらと推測された，以上の所見か ら， liver fibrosis では，ラ氏島細胞の 機能え進を示唆 する所見が得られたこれらは機能的にすIRI 值が上 昇することとも一致しているように思われた，一力， liver cirrhosis B では liver fibrosis のラ氏島 B 細胞にみ られたよらな顆粒の core の density の著しく高い顆粒 や細胞間陵に存在した amorphous な物質の存在はみら れなかったが，個々のラ氏島 B 細咆の細胞内小器官に機 能充進状態がうかがわれ，機能的にも liver fibrosis 上 り IRI 值がより低值を示しているのと一致するようで あった，一方， liver cirrhosis A の場合は, liver fibrosis p liver cirrhosis B の場合とは異なり，A 細胞に著 明な細胞数の增加，即ち $\mathrm{A} / \mathrm{B}$ 比の增大傾向がみられ， また個々の $\mathrm{A}$ 緇胞についても Golgi 装置の発達る良好 で，B細胞に比し退行性変化の極めて少ない像が淮察さ れた. 以上これらの所見は liver cirrhosis A では IRG 值の著明な上昇が欢らたことと一致していることが何 えた，一方， B 細胞については，分泌顆粒む豊富で， Golgi 装置の発達の上いむのもみられるが，大多数の細 胞では粗面小胞体の槽の拻大がみられ，槽内には amorphous な物質るみとめられず，空胞化しているものもみ られた，そしてさらに変化の著しいものでは，細胞貿全 体の density が著明に高くなり，細胞菱縮を和もわせる 像がみられた。

以上, 肝障害時の膡の機能と形態について検討した絬 果，肝障害の比較的軽度な時には膵ラ氏島 $\mathrm{B}$ 細胞が極め
て活発で，肝障害がすすみ liver cirrhosis A となると， 5氏島 $\mathrm{B}$ 細胞の退行性変化がみられるが，一力，A 細胞 については退行性変化は忹とんどみられず，むしろ，活 発な状態が観察されたこのような現象がいかなる原因 によって生じたるのであるのか，肝細胞の障害による滕 の代償的な作用のみではなく，肝との相関と颃いて，肝 よりあるいは他の茼器より何らかの因子の関与の可能性 屯考慮され，今後，さらに検討する必要があるう，しか 几，以上の成績が四塩化宸素による実験モデルであるの でこれれらの実験モデルから得られた結果が人肝障害患 者の場合に同様な結果としてみとめられるかどうか明ら かでない，また，四塩化炭素の膵への直接影響について る検討する必要がある. この点汇関して, Castro ら ${ }^{13)} の$ 報告もあるが，Recknagel ら ${ }^{14)}$ p Rao ら ${ }^{15,16)}$ は四塩化炭 素の細胞障害のメカニズムとして，四塩化炭素は肝細胞 内のミクロゾームにとりこまれ， $\mathrm{CCl}_{\mathrm{s}}$ (trichlor methyl free radical) となり不飽和脂肪酸と結合し，細胞膜障害 をきたし，過酸化物となって， lipid droplets を生じ細 胞内に蓄積される，そして，これらは不可逆性の安定し た物質となると報告している，従って，少量の四塩化炭 素の投与ではきわめて選択的に肝に障害をむたらすとの べている。 また脚にはチトクローム P450 の存在が証明

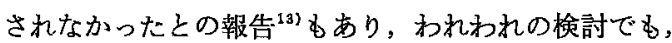
正常䅈に比して，著明な变化はみられなかった。また 般に細胞毒とされている四塩化炭素が，直接ラ氏島細胞 に作用し，機能え進をむたらすとも考党にくい．以上の ことから，四始化炭素の膵への直接影響は全面的に否定 することはできないが，それによる影響が極めて少ない ことが推測され，人肝障害時の脺ラ氏島の変化を倹討す る上で，示唆に富む所見と考えられた。

\section{V. 結 語}

四塩化炭素による肝障害ラットでは，肝障害の軽微な あのではラ氏岛 B 細胞の機能立進がみられ，高度なもの では A/B 比の増大傾向， $\mathrm{A}$ 細胞の機能充進がうかがわ れ，末梢血の IRI 出よび IRG 值の変動る肝障害による 耐糖能の低下以外に，膦亏氏島細胞の影響も無視出来な い上うに思われた。

\section{文献}

1）橋本 仁，山下隆史，坂崎庄平，他：盰硬変症 に扎ける膵ラ氏島細胞の電子顕微鏡的考察，儖 本電䫓誌 $12: 133-143,1979$

2) Johnston DG, Alberti KGMM, Faber OK, et al: Hyperinsulinism of hepatic cirrhosis: 
Diminished degradation or hypersecretion? Lanset 1: 10-12, 1977

3) Van Goidsenhoven GE, Henke WJ, Vacca JB, et al: Pancreatic function in cirrhosis of the liver. Amer J Dig Disease 8: 160—173, 1963

4) 大垹 守: 肝硬変・肝癌展に和ける勝の組織学 的研究. 日消会誌 $62: 1089-1103 ， 1965$

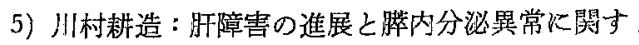
万研究. 肝蔵 $7: 320-339,1966$

6) 広瀬昭一郎, 武内重五郎, 高田 昭 : 肝疾患時 の膵障害. 最新医学 $27: 1764$-1770, 1972

7) 森 克己：肝疾患と糖尿病, Diabetes J 3 : $66-77,1975$

8) Megyesi C, Samols E, Marks V: Glucose tolerance and diabetes in chronic liver disease. Lancet 18: 1051-1055, 1967

9) Sherwin R, Joshi P, Hendler R, et al: Hyperglucagonemia in Laennec's cirrhosis; The role of portal-systemic shunting. N Engl J Med 290: $239-304,1974$
10) Shurberg JL, Resnick RH, Koff RS, et al: Serum lipids, insulin and glucagon after portacaval shunt in cirrhosis. Gastroenterology $72: 301-304,1977$

11) 武内重五郎, 高田 昭, 杉䫺五郎, 他 : 糖尿病 と肝障害. 最新医学 $19: 329-344,1964$

12）山吹隆寛，木村健一：肝機能障害とステロイド 蛕尿，糖尿病 6:21-34，1963

13) De Castro CR, Bernacchi AS, DeFerreyra EC, et al: Carbon tetrachloride induced ultrastructural alterations in pancreatic acinar cells and in the hepatocytes. Similarities and differences. Toxicology 11: 289-296, 1978

14) Recknagel RO: Carbon tetrachloride hepatotoxity. Pharmacological Rev 19: 145-208, 1967

15) Rao KS, Recknagel RO: Early incorporation of carbon-labeled carbon tetrachloride into rat liver particulate lipids and proteins. Experi Mole Path 10: 219-228, 1969

\section{Morphological and functional studies of experimental hepatic damage induced by $\mathrm{CCl}_{4}$}

\section{Hitoshi Hashimoto, Eiji TaRUYa, Takafumi Yamashita and Kaoru UmeYama*}

Experimentally we experienced various liver damages in rats by injecting with $\mathrm{CCl}_{4}$ into their peritoneal cavity, and we studied the function and the histology of pancreatic endocrine cells in these rats. By electron microscopic observations, $B$ cells in the islets were hyperfunctioning state in the liver fibrosis. But in the liver cirrhosis A, the ratio A and B cells showed a tendency to increase, and IRG in the serum demonstrated markedly high level. From these results, it was suggested that the changes of the serum IRI and IRG were due to not only the hepatic damage but also the function of the pancreatic islets.

\footnotetext{
* The First Department of Surgery, Osaka City University, Medical School (Osaka)
} 